\title{
Criminal Review Board of Forensic Psychological Evaluations in Relation to Appeal Hearings: A Culturally Responsive Police Accountability Paradigm
}

\author{
Johnson $\mathrm{R}^{*}$ and Saadatzadeh $\mathrm{Y}$ \\ University of San Diego, School, Family, Mental Health Professions, California, USA
}

${ }^{*}$ Corresponding author: Johnson R, Ph.D., ABPP, University of San Diego, 3525 Del Mar Heights Road Suite 302, San Diego, CA. 92130, USA, Fax and Tel: 858-793-6899, E-mail: ronnjohncts@gmail.com

Citation: Johnson R (2016) Criminal Review Board of Forensic Psychological Evaluations in Relation to Appeal Hearings: A Culturally Responsive Police Accountability Paradigm. J Forensic Sci Criminol 4(3): 301. doi: 10.15744/2348-9804.4.301

Received Date: December 13, 2015 Accepted Date: June 28, 2016 Published Date: June 29, 2016

\begin{abstract}
Purpose of this paper: This paper provides a paradigm for the creation of a civilian review board. To illustrate this model, themes of a civilian board's connection to the community, establishment of the board, and criminal psychological implications for the future of the selection and retention of police officers are discussed. High profile police incidents (e.g., Freddy Gray, Charleston, SC and Chicago Police Shooting Laquan McDonald, etc.) have forced departments to grapple with a question that has long been latent in the experiences of ethnoracially diverse citizens. What is generally known about frequency and types of crimes committed by police? Answering this question, may function as justification for or against greater external citizen review of suspected crimes committed by police.
\end{abstract}

\section{Design/methodology/approach (N.A.)}

Findings: Police officers provide public safety and community trust can dampen confidence in officers if there is no perceived ethnoracially credible accountability structure for departments.

Research limitations/implications: Community and organizational research can be conducted that explores a host of safety related variables stemming from departments that have citizen review boards.

Practical implications: The paper assesses how recent high profile cases such as those in Ferguson, Missouri, and Baltimore, Maryland, illustrate the need for proper screening and selection of police officers today. In order to increase a community's trust in the police, public involvement is a necessity. Practically speaking, what does this mean for diverse communities of citizens with respect to the criminal review of police conduct? It can result at a minimum in the development of new policies that contain provisions requiring police departments to (1) incorporate significant ways to give citizens access to information relevant to police misconduct (2) change the membership of current police review processes and structures (i.e., appeal hearings) to include representative citizens (3) review current and craft new compliance and ethical standards within the department with respect to suspected police misconduct. The objective of this paper is to discuss issues relevant for diverse citizen involvement in appeal hearings in relation to forensic psychological evaluations of incumbent police officers.

Establishment of an independent civilian review board in the screening and selection of police officers would not only increase the trust of the police department, it would also provide a culturally responsive framework that allows the community to be involved with police departments.

Social implications: There are two potential social implications. First, an independent citizen review board would function as a critical factor in maintaining community trust in the police department. Second, public safety is an outcome that can be achieved from citizens and police officers.

What is original/value of paper: The distinctive contribution of this paper is the focus on the role the CRB can play in ethnoracial communities and in the nexus to police officer safety.

Keywords: Citizen Review Boards; Criminal Psychology; Police Misconduct; Forensic Psychology

\section{Introduction}

A repeated history of police misconduct and excessive use of force along with what is viewed as a lack of accountability have been ongoing subjects of dispute for many years. With high-profile incidents occurring presently, such as those in Ferguson, Missouri and Baltimore, Maryland, a significant amount of the public has witnessed an erosion of trust in their own police departments. The complaints about police officers range from a variety of issues, with a sharpened focus on the selection of police officers. This discontent has resulted in communities feeling less confident in the process by which police officers are screened, selected, trained, 
and supervised. When perceived high-profile, excessive-force incidents occur, the screening and selection process of police officers becomes questioned. Presently, the selection of police officers varies by region. However, there is an emphasis on "fitness-forduty" and a focus on the individual's past history whenever an incumbent officer's behavior comes into question. Currently, the processes being used are not garnering trust from the community. In order to establish a palpable level of credibility and trust, a civilian review board for the selection and retention of police officers may be of considerable benefit, particularly in the aftermath of high- profile in-custody death cases.

The high-profile misconduct incidents occurring in Ferguson and Baltimore have sparked a series of protests due to the incidents raising questions among the public surrounding police misconduct. For example, the incident in Ferguson started when the responding police officer, Darren Wilson, asked two individuals to move from where they were walking [1]. One of these individuals (i.e., Michael Brown), fit the description of a man who was previously identified as a suspect in a convenience store theft [1,2]. After Officer Wilson called out to dispatch about Brown, an altercation ensued which resulted in Wilson firing multiple shots ultimately killing Michael Brown. Wilson's testimony indicated that he believed Brown was reaching for a gun and charging toward him before he was shot. Although some witnesses on the scene stated that this was not the case, the officer claimed that he feared for his life. In time, a grand jury chose to not indict Officer Wilson in the death of Michael Brown [1]. The failure of the grand jury to indict Wilson seemed to fuel a "wave of anger" in the public; buildings were set on fire, and there was widespread looting of businesses nearby [1,2]. In addition, protestors threw a variety of objects at police officers, and the officers relied on military-style equipment and tear gas to disperse the crowds.

The killing of Michael Brown sparked outrage from the public surrounding tactics used by police that are considered police misconduct [2]. By contrast, Captain Ronald Johnson of the Missouri Highway Patrol decided to signal a change regarding police response tactics in what the officers were doing in response to the community [3,4]. During the Ferguson riots, Captain Ronald Johnson was placed in charge of the scene. As a result, his leadership rapidly resulted in steps being implemented that buttressed public safety, while at the same time establishing legitimacy through procedural justice. In this case, his actions resulted in a balancing of the need for restoring peace while exercising the law enforcement's legitimate authority which had ostensibly been non-existent due to decades of a perceived lack of procedural justice. He ordered that officers remove their tear-gas masks (thus ending the use of the gas) and ordered the removal of armed personnel vehicles and police cars [4]. Although this tactic only worked for a short period of time, Captain Ronald Johnson's efforts reinforced the relevance of police selection and retention [3]. The approaches used by Officer Darren Wilson and Captain Ronald Johnson are significantly different, which leads to the speculation surrounding their process of selection to become police officers.

The diverse incidents involving Darren Wilson and Ronald Johnson are telling reminders of a need for proper selection and retention of police officers. In these cases, there was a legacy of police misconduct that seemingly led to a loss in public trust for the police departments in the Baltimore and Ferguson communities [4]. A faulty selection and retention process can lead to diminished credibility of the police as well as litigation and costly payouts stemming from police misconduct. The International Association of Chief's of Police (IACP) outlines forensic psychological procedures for law enforcement agencies. These processes include the psychological screening for all sworn public safety applicants (i.e., Johnson and Wilson) in advance of being hired or selected. After becoming an incumbent officer, a department administrator has the authority to direct any problematic officer to a post-hire (i.e., fitness for duty psychological) evaluation if there are concerns (i.e., based on their actions or lack thereof) regarding performance of sworn duties. However, cases like Captain Ronald Johnson appear to underscore the relevance of a practice of selecting police officers that understand the needs and priorities of the community. The selection process for Captain Johnson and Officer Wilson were more likely than not similar in many ways, which speak to the need for supervision and training. In sum, despite reflexive resistance from unions, there is a growing need for citizens to assume an authoritative decision-making role in department processes, psychological screening, selection, appeal boards, training, and supervision of police officers.

Due to the increasing public awareness of excessive force incidents, there is a need for proper standardization of screening and selection measures [5]. The process for screening, selection, and retention of police officers varies by region; however, there are some similarities between many departments. For example, a representative number of departments rely on methods that include written tests, background investigations, physical examinations, and interviews [6]. If supervisors suspect that an officer displays behaviors that can lead to problematic behavior or a decline in their work performance, they may set into motion the steps required to secure a psychological fitness-for-duty evaluation (FFDE) [7]. Theoretically, through this examination, departments can ostensibly determine if an individual's psychological functioning is somehow compromising his or her ability to perform their duties. It is also important to note that the FFDE can provide reasonable justification for termination of an officer who cannot meet the standards of their agency. Even though the International Association Chiefs of Police (IACP) does provide recommended standards for these evaluations, in terms of psychological testing during the FFDE, there is no universally used psychological test battery.

However, in some cases, psychological tests used during an FFDE could include areas on general intelligence, cognitive-functioning, personality, mood, and any existence of psychotic symptoms [7,8]. Although there are no universally used psychological test batteries used as of the present, there are psychological tests available that have shown predictive validity of performance including the National Police Officer Selection Test (POST), Minnesota Multiphasic Personality Inventory-2 (MMPI-2) and the Inwald 
Personality Inventory (IPI) [9-14]. Once the FFDE is completed, a recommendation from the examiner remains. Currently, there is no standard model for FFDE recommendations, but one protocol that has been determined to be useful includes: Unfit for duty, unfit but treatable, no psychological diagnosis, and invalid evaluation $[7,15,16]$. In addition, the decision-making processes must also include representative bodies from the community in order to increase trust and reinforce the perception of accountability within police departments.

\section{Past Civilian Oversight}

From a historical community perspective, it is critical to understand how other countries use Civilian Review Boards (CRB), as well as how the public views them in order to further reinforce implementation of a CRB method. Doing so may provide more formal authority in the selection, retention, and appeal processes in the United States Police Departments. The concept of civilian oversight of police is not new and has existed since 1928 [17,18]. Although, CRB's for police officers are not seen often in the United States, but other countries, such as the Philippines South Korea and Canada, have adopted a civilian review board method which still in a current practice $[17,19,20]$.

The Philippines provide one example of a CRB application, when the Philippine government formed the People's Law Enforcement Board (PLEB) in 1991 and developed a goal to increase authority of civilians with respect to police departments when handling complaints made against the police [19,21]. In total, there are 28 PLEB's in the region, and every city has at least one PLEB. The board is composed of "any member of the Sangguniang Panglunson/Bayan (city or municipal council)" chosen by their respective council, a Barangay captain of the city or municipal council picked by the Association of Barangay Captains, and three other members chosen by the Peace and Order Council from the community the PLEB will be in [19,22]. Of the three members, one must be a member of the Bar, a college graduate, or a principal of an elementary school in the community however a member of the Bar is preferred [23]. Each member is carefully selected and screened, and will be replaced if that member does not meet qualifications. PLEB members are selected for a duration of two years, and do not receive any definite compensation for their work [23]. Once the PLEB is formed, it is tasked with receiving a variety of complaints made against the police. It has the authority to issue penalties for the police that can range from reprimand to removal. In addition, the PLEB has the power to issue subpoenas or suspensions if required. PLEB decisions are always subject to appeal.

One might expect there would be disconnect or unwanted levels of dissatisfaction towards the PLEB in the Philippines. However, there appears to be both public and police satisfaction with the process [19]. In one study exploring satisfaction of complainants (individuals who served a complaint against the police) and police officers with the PLEB, it was found that 51 percent of police officers with a case against them were only dissatisfied with the composition of members in the PLEB. Both police officers with a case against them and those with no case against them were found to be more satisfied than dissatisfied in all other aspects of the PLEB [19]. Additional findings include that complainants were very satisfied with all aspects of the PLEB. These CRB-relevant findings reinforce evidence-based practices that suggest they can be both beneficial and satisfactory for the public as well as for the police officers themselves.

Similar to the experience in the Philippines, South Korea has an impressive history of a commitment to ensuring that police organizations are focused on adherence to fundamental laws, protection of human rights, and democratic policing [17]. In fact, actual police reforms started in the 1990s with the sole purpose of increasing police accountability and allowing the public to contribute more to police oversight. As a part of this reform, the Korean National Police Agency (KNPA) created the Office of Hearing and Inspection (OHI) in 1999 [17,24]. Members of the OHI consist of police officers appointed by the chief of the KNPA. The purpose of the $\mathrm{OHI}$ is to investigate citizen complaints regarding police misconduct in order to obtain the trust of the public [17]. Although OHI was established, many citizens were dissatisfied with its process because of the fact that all of its members were police officers $[17,25]$.

Due to the dissatisfaction of the OHI, the Civilian Review Committee (CRC) was created in 2005 by the KNPA, with the goal of reviewing the internal inspection procedure [17]. The CRC consists of nine civilians who serve a term of two years. The members of the CRC review allegations and/or complaints against high-ranked officers, and then recommend a decision to the Commissioner General. Although this committee increased the participation of the public in police-related matters, the public remained dissatisfied because police officers were the ones completing the investigations. In May of 2010, the president of South Korea initiated the formation of a new CRB program in response to an upsurge of police excessive force, misconduct, and corruption $[17,26]$. The formal CRBs allowed for the public to be more involved and were established in 16 state police agencies; its members included academics, non-academics, and legal professionals $[17,27,28]$. The CRB's were officially created on August 21, 2012, and included 91 appointed members whose goals were to investigate corruption and misconduct charges [27,29]. Similar to the Philippines, this CRB group was able to submit recommendations for disciplinary action, but they did not have the authority to make the final decision themselves.

As a result of the recent development of the CRB's in South Korea, there is a paucity of literature on its acceptability amongst the public and police officers. However, there is some research on perceived acceptability amongst police officers prior to the establishment of CRB's. The findings from one investigation revealed that about one-third of police respondents ( 406 responses in total) were in 
favor of establishing a CRB [17]. In addition, it was found that there was a negative correlation between years of experience and the officers' perception of CRBs. That is, the longer an officer's tenure with the department, the lower their ratings of the CRB. Nonetheless, there was a positive correlation found among officers'perceptions of public support and the establishment of CRB's. These findings appear to suggest how police officers may view the establishment of a CRB and may shed some insight as to how this might work in North America (e.g., Canada).

Police corruption and misconduct in Canada has been documented since the early 1950's in the form of prostitution and gambling [20,30]. Recent incidents include assaults, freezing deaths of aboriginal men in Saskatchewan, and corruption. Due to these incidents as well as poor public-police relationships, the Metropolitan Toronto Police Force Complaints Project Act was introduced in 1981, and the goal was oversight of the police [20,30]. Initially, the review board was not very successful largely for two reasons. First, the review board only focused on the Toronto police. Second, the board's scope of work focused only on monitoring the investigation and initiating a review of claims made against a police officer. In 1984, the CRB was made permanent, and the Police Services Act in 1990 expanded the oversight to include all police services in Ontario [20,31]. The CRB consists of a "chair, commission counsel, senior, full and part time investigators," case managers, and administrative coordinators chosen by the Lieutenant Governor [20,32]. The complaint process requires that the board review complaints and make recommendations as to what actions should be taken to resolve them. Many citizens were in favor of the new act because it allowed them to file complaints with a separate agency, as opposed to filing complaints with the actual police department. In addition, the CRB was charged with updating the complaints every 30 days, which meant that the CRB had to be current or timely in reviewing cases that were brought before it.

As expected, the Ontario Provincial Police Association was not in favor of the CRB process. Legislative proposals were created to decrease the power of the CRB's, and in 1997, Bill 105 was passed whose purpose was to increase the discretionary authority of the police chief in reviewing complaints [20]. In practice, the police chief has the ability to dismiss claims deemed "in bad faith," or to take no action if he or she was believed to not be directly involved with a case. Nevertheless, other Canadian provinces began establishing their own CRB's due to the increasing demand of civilian oversight. Currently, there are 18 civilian review boards operating in Canada [20,33]. Most officers are not in favor of the CRB process, and the public is still hesitant due to the amount of discretionary power afforded the police chief. [34,35].

Unlike the countries previously discussed, the idea of a CRB arose quite earlier in the United States, beginning in the 1920s with Los Angeles, as a result of a pattern of police abuse, misconduct, and corruption. [20,36]. Proposals for a CRB were made throughout the years, including 1931 when the Wickersham Commission recommended establishing "some disinterested agency" to help take care of citizen complaints $[18,20]$. Although there was interest in the formation of these boards, many proposals were ignored until the 1940s, when racial tensions and riots erupted in various cities including New York, Detroit, Washington D.C., and Los Angeles. These continuing incidents finally led to the formation of the first CRB in the United States.

In 1948, the CRB for the Metropolitan Police in the District of Columbia was formed [18,20]. The CRB included three citizens, chosen by the police chief, who received complaints and made suggestions for repercussions for each case. Although there was interest with all parties involved, politicians and law enforcement were successful in impeding the development of the CRB, and the board remained in existence until the mid-1990s. In 1958, Philadelphia produced another oversight agency, called the Philadelphia Police Advisory Board. This CRB consisted of citizens who were chosen to review complaints, refer them for investigation by the police department, and then make recommendations after reviewing the investigation reports [20]. This CRB lacked support from both the public and the administration, which led to its collapse in $1969[18,20]$. Although the former CRB collapsed, CRBs continue to form due to public demand following recurrent police corruption and misconduct. Today, there are over 100 police agencies with CRB's in the United States however, none of them are directly involved with the selection, retention, or appeal processes of police officers $[37,38]$.

\section{Connection to the Community}

The high-profile shooting cases and the on-duty assassination deaths of police officers have led to a need to redefine (i.e., narrative and practices), the connecting tale of two sides (i.e., role of citizens and police). The Hebrew word for connecting is "mithabrim." And, a CRB ostensibly may function as a way of achieving a culturally responsive "mithabrim" between the community and police department through accountability that is fueled by an independent Citizen Community Review Board. Accountability and community connections have emerged as two signature components required for maintaining public safety in ethnoracially diverse communities like Baltimore and Ferguson. In these cases, community connection strategies that are focused on achieving sustainable ethnoracial trust are sine qua non in twenty-first century culturally responsive policing. Good cops have long respected the practice that community relationships are foundational to their safety and a must if they are to be assessed as successful in carrying out their duties. For example, a good cop is to exercise an appropriate command presence given the hierarchical nature of their contacts with diverse citizens. In comparison to citizens of the community, police officers are considered to be of higher power due to what their job entails. 
These repeated encounters must occur without carryover or residual baggage from their personal life (e.g., previous negative experiences with different ethnic or racial groups), or the lingering accumulative effects from previous negative police-citizen emotionally charged incidents [7].

There have been a series of what some have assessed as racially charged police incidents (e.g., Ferguson, Charleston, SC and Staten Island, NY) that has resulted in pockets of erosion in the public's perception of accountability and trust in police. That is, accountability and ethnoracial trust are surprisingly scarce based on the perceptions and misperception of the individuals residing in diverse communities, evidenced by the international protests following several deadly force incidents [18]. Over time, no police department can survive in a perceived adversarial relationship with ethnoracially diverse communities.

In what appears to be a concentrated period of time, several ethnoracially diverse communities have undergone volcanic-like eruptions in response to officer-involved deaths. The triggering of these citizen responses may be attributed to a perceived rupture in the rule of law signaled by a gaping hole in the social fabric of the community (i.e., potentially bad cops who are not being held accountable for their actions). Not every citizen on a national basis grabs a sign or walks in a march to protest against the criminal justice system and police. Even during protests, most people generally behave peacefully and comply with police requests. They also do not participate in destructive or criminal activities during protests or use them as a conveniently cloaked scheme to achieve their unwanted illegal motives. However, for legitimately concerned citizens, the decision to protest poses a potential safety risk for them and is a stressful action because they are painfully aware that not all protestors are ostensibly from the community or have the same peaceful protest motives. They also recognize that not all cops are equally competent in being able to properly differentiate between those protestors who are law-abiding and those who are anarchists, terrorists, or just plain criminals [39-41].

The occupation of a police officer is a difficult one to have, and not everyone is psychologically suitable to function in the comprehensive and stressful role of a police officer. There is no shortage of good applicants or individuals aspiring to become police officers; each year, thousands of individuals apply for and are rejected by various departments. [7,42]. The standards for being a sworn weapons-carrying police officer are much higher than civilian and military positions. This position is a weapons carrying public service job that requires a rigorous forensic psychological screening, appeal process, selection, and training [43,44]. Police work has a political psychological component as well although no police officer should be allowed to wear their uniform to protest their grievances. Any officers that do so, must be terminated because such ill-advised actions cast serious doubts about the unbiased and professional nature of the department. Once an individual becomes a police officer, the individual is not entitled to a lifetime of employment with no expectation of demonstrating cultural competence and continuously demonstrating psychological suitability for the position. The authority to use the power of arrest and deadly force in an effort to legally maintain public safety by default requires the ethnoracial trust from the community as well as full confidence that those duties are being properly discharged (i.e., culturally or ethnoracial credible accountability [44,45].

Most departments have units or a collection of policies that are organized to operate in an effort to review police conduct. However, something is missing or not at a level that the community feels satisfied that the police department is properly discharging their duties on a consistent basis with diverse citizens.

What is apparent is that in many of these CRBs there are insufficient connections to the ethnoracially diverse communities. In order to develop trust in a community, a successful CRB must have direct ties back to the actual community itself. Once a board is created, the board members must be proactive and have ongoing communication with the public regarding their role while allowing the public to voice any concerns they may have [46]. To illustrate, in 2001 the New York Civilian Complaint Review Board (CCRB) created "outreach" activities that included a series of town hall meetings. The goal of these meetings was to allow the public to participate in an "open forum" where they could voice their opinions, ask board members questions about the CCRB system, and make a complaint [46]. Although the meetings did not last more than a year due to the CCRB's workload, the board did find that the meetings were beneficial to the community. In essence it gave them the opportunity to learn more about police job tasks that were outside of the complaint investigation process. It also permitted them to listen and respond to concerns that the members of the public had, thus building trust with the community, which in effect contributed to public safety (i.e., citizens and police officers).

Although presently there is a paucity of literature on the effectiveness of connecting the outside community to something similar to the proposed CRB, research has demonstrated that informational sessions can result in the public giving positive evaluations for both the meetings and of police officers [47].

\section{Establishment of a Civilian Review Board}

In order for a CRB to be beneficial to all parties involved, the CRB must have certain components that focus on the psychological well-being of police officers. However, because "civilians" will be of course involved in this process, trust needs to be earned from the community as well. To be credible (i.e., to have integrity and objectivity), a competent board must be trained to recognize the diverse public safety services required for the community (e.g., emergency responses, mentally ill residents, neighborhood watch groups). Internationally, twenty-first century selection and retention of police officers must include some type of recurring ethnoracial rating system that designates an officer's competency to work in diverse communities [48-52]. It also means that the 
diversity found in the community must at least be proportional in all the professional groups involved in the selection, screening, appeal process, and retention of law enforcement personnel. An independent citizen accountability board must have at least three elements. First, the CRB must have an assessment or accountability arm that has the potential to facilitate a community-based sense of confidence that police officers are uniformly ethnoracially competent as well as consistently operate with fairness, integrity and objectivity while carrying out their duties [53,54]. In addition, officers must also be suitable and psychologically stable. Second, an expanded or revised role for CRB must include an intervention arm that works with the department and community to achieve a transformation that requires separating the emotional discontent into a more unified healing whole [55]. That is, this arm should make recommendations to the department and work towards improving negative community perception and prevent police misconduct. Finally, the CRB must provide feedback to the community without violating the highly confidential and public safety nature of their work.

As discussed previously, there is a lack of ethnoracial trust for police officers among the community. Several high-profile deaths involving unarmed Black males have resulted in a daunting police task of restoring this trust. A trust that may be partially achieved through post- Baltimore and Ferguson versions of CRBs that are tasked with reviewing the psychological stability and suitability of each officer in a department at least every five years or sooner depending on the circumstances. The same CRB would also review the psychological stability and suitability of every officer involved in a cross-ethnoracial incident (e.g., OIS or citizen complaint). The CRB would function in an advisory capacity to the chief of police and the elected authority or administrative person responsible for the police department. It can also function as a credible voice to the community in the wake of high-profile incidents involving police officers.

It is beyond the scope of this article to detail all of the logistics (e.g., administration, strategies for receiving community input, qualifications of members, community assessment of ethnoracial trust, and funding), of this specialized CRB. However, CRB's must craft comprehensive statistical reports redacted for personal identifying information but nonetheless reflective of their transparent activities. In addition, the job of CRBs should entail various forensic psychological risk ratings for police officers (e.g., suitable, not suitable, stable, not stable), assessing comments from citizens, and making recommendations to the department. For example, in terms of police officers, the entangled nature of policing in diverse neighborhoods requires awareness of historical trauma in the absence of cultural healing. This awareness must be included as a competency that all police officers have to pass during the academy, integrated within the Field Training Officer (FTO) experiences and present in a significant way in subsequent continuing education for all police officers [56]. The CRB can function as an independent advisory crosscheck for the selection and retention of police officers. The CRB must periodically (i.e., at least three times a year or following every high-profile incident) announce accountability public forums where they invite comments and provide information about their activities. The repeated meetings throughout the year may have dual benefits to the police department. First, it functions as a viable portal for establishing a recognized forum for community diverse citizens which can minimize or prevent reflexive adverse reactions in the aftermath of high profile police incidents. Second, these recurring meetings serve the role of transparency, which are vital for facilitating legitimacy and perception of procedural justice.

Police work is one of the few public safety professions that require officers to be able to forge appropriate partnering relationships with all the groups that make up a diverse community.

In practice, the construct of "community connections" means that police officers must function as a multiple-port public safety USB hub for all of the diverse constituents that make up the community. Similar to the New York CCRB, the proposed CRB should provide meetings in order for a community connection to be formed. This structure can include information sessions (i.e., to provide information about the board and allow the public to ask questions), along with recurrent meetings to allow for communication with the public. When creating these meetings, it may be helpful to include police officers so that the public can direct their questions towards them if necessary [57]. Additionally, the inclusion of police officers could be beneficial in order to mediate any issues that can be quickly and easily addressed [58]. The critics or detractors of CRB's, provide a counterargument that is perpetuated on a belief that the current culture of police is unbroken. In addition, the disciplinary and checks being used now adequately take care of the concerns raised by ethnoracially diverse groups. Finally, police are not racist, and its presence is no more noteworthy than it is in the general civilian population.

\section{Future Criminal Psychology Implications and Conclusion}

The future of policing in diverse communities must include CRBs. Such boards would have a transparent advisory role with the chief and appropriate elected officials in all matters related to complaints, high-profile incidents, retention screening, selection, training, research, and review of police officers. All CRB activities and resulting recommendations would be made public. It is in the publics interest to maintain oversight and work in partnering with departments to have officers that can maintain the fullthroated support of ethnoracially diverse communities. Therefore, the objective of this article is to broaden the understanding of how the police must function in being accountable while making diverse public safety a priority. A failure to achieve and maintain citizen trust means the police departments should be revamped into a model that is consistent with the values of the community as a whole [59]. 
When it comes to policing diverse citizens, the past is prologue. The authors believe that overtime, police officers build a brand reputation (e.g., unbiased and competent), based on how the diverse individuals historically perceive a legacy of experiences with them. Unfortunately, the history of contact with police officers contains a significant number of incidents that call into question officer judgment whenever they engage diverse citizens during various lawful contacts. To become a police officer, one has to swear an allegiance to an oath of office [60]. This oath fully recognizes that fully recognizes that being a police officer is a stressful and tough job that is not psychologically suitable for anyone who cannot serve in a way that maintains the trust of the community. Police officers must be students of ethnoracial history and possess the highest level of personal integrity. When an officer engages in any conduct (i.e., on or off duty), police integrity must replace the ethnoracial legacy of hypocrisy which undermines the credibility of police officers as a whole For example, one day after the beating, Rodney King's brother arrived at LAPD to report the incident, but was denied an opportunity to file a complaint [61]. Internationally, it has been demonstrated that the perceived legitimacy and procedural justice can be developed in a way that promotes public safety in ethnoracially diverse communities.

It is the glaring pockets of police misconduct that make it a public safety necessity to have independent CRBs in place for all police departments.

\section{References}

1. Buchanan L, Fessenden F, Lai R, Park H, Parlapiano A, et al. (2014) What happened in Ferguson? The New York Times.

2. Davey M, Fermandez M (2014) Security in Ferguson is tightened after night of unrest. The New York Times.

3. The New York Times (2014) Tracking the events in the wake of michael brown's shooting. The New York Times.

4. Schwartz J, Shear MD, Paulson M (2014) New tack on unrest eases tension in Missouri. The New York Times.

5. Walker SE, Archbold CA (2014) The New World of Police Accountability. Thousand Oaks, CA: SAGE Publications, Inc.

6. DeCicco DA (2000) Police officer candidate assessment and selection. FBI Law Enforce Bul 69: 1-6.

7. Miller L (2007) The psychological fitness-for-duty evaluation. FBI Law Enforcement Bulletin 76: 10-6.

8. Johnson R (2013) Forensic psychological evaluations for behavioral disorders in police officers: Reducing negligent hire and retention risks. In J Heflgott, ed. Criminal psychology (Vol. II). Westport, CT: Praeger.

9. Henry MS, Rafilson FM (1997) The temporal stability of the National Police Officer Selection Test. Psychol Report 81: 1259-65.

10. Rafilson FM, Sison R (1996) Seven criterion-related validity studies conducted with the National Police Officer Selection Test. Psychological Reports $78: 163-76$.

11. Cochrane RE, Tett RP, Vandecreek L (2003) Psychological testing and the selection of police officers: A national survey. Crim Justice Behav 30: 27-38.

12. Simmers KD, Bowers TG, Ruiz JM (2003) Pre-employment psychological testing for police officers: The MMPI and the IPI as predictors of performance. Int $J$ Police Strategies Management 5: 277-94.

13. Tarescavage AM, Corey DM, Ben-Porath YS (2014) Minnesota Multiphasic Personality Inventory-2-Restructured Form (MMPI-2-RF) predictors of police officer problem behavior. Assessment 1-17.

14. Detrick P, Chibnall JT (2002) Prediction of police officer performance with the Inwald Personality Inventory. J Police Criminal Psychol 17: 9-17.

15. Rostow CD, Davis RD (2004) A handbook for psychological fitness-for-duty evaluations in law enforcement. New York, NY: The Haworth Clinical Practice Press.

16. Rostow CD, Davis RD (2002) Psychological fitness for duty evaluations in law enforcement. The Police Chief 69: 58-66.

17. Kang W, Nalla MK (2011) Perceived citizen cooperation, police operational philosophy, and job satisfaction on support for civilian oversight of the police in South Korea. Asian Criminol 6: 177-89.

18. Walker S (2001) Police accountability: The role of citizen oversight. Belmont CA: Wadsworth.

19. De Guzman MC (2007) Integrity of civilian review: A contemporary analysis of complainants' and police officers' views in the Philippines. Police Practice Res 8: 31-45.

20. Ferdik FV, Rojek J, Alpert GP (2013) Citizen oversight in the United States and Canada: An overview. Police Practice Res 14: 104-16.

21. Gutang R (1993) Pulisya. Manila: Rex Bookstore.

22. NAPOLCOM Memorandum Circular No. 91002

23. De Guzman MC (2004) One for all? Philippine police officers' perceptions of civilian review. Policing: Int J Police Strategies Management 27: $358-79$.

24. Moon B (2004) The politicization of police in South Korea: A critical review. Policing: Int J Police Strategies Management 27: 128-36.

25. Yang M, Lee D (2006) A study on the strategic internal affairs system against corruption in Korean police. Korean Association of Public Safety and Criminal Justice Journal 22: 291-320.

26. Choo S (2010) The President indicated the importance of police reform. Yonhap- News.

27. Nalla MM, Mamayek C (2013) Democratic policing, police accountability, and citizen oversight in Asia: An exploratory study. Police Practice Res 14: 117-29.

28. Park J (2010) Police establish Civilian Review Board. Donga-Daily.

29. Min K (2012) Establishment of citizen review board. Yonhap News 2A.

30. Campbell E, Mahaffy N, Stewart D, Trepanier M (2004) Canada's approach to battling police corruption. 18th International Conference of the International Society for the Reform of Criminal Law. Miller Thomson LLP.

31. Landau T (2004) Back to the future: The death of civilian review of public complaints against the police in Ontario, Canada. In Goldsmith A, Lewis C, eds. Civilian Oversight of Policing Portland, OR: Oxford Publishing 63-83.

32. Ontario Civilian Commission of Police Services (2011) Annual report - 2010.

33. Canadian Association for Civilian Oversight of Law Enforcement (CACOLE) (2012) List of Canadian oversight agencies. 
34. Kedmey D (2014) Ferguson Creates Citizen Review Board to Check Police Conduct. Periodical. Time.com 9/9/2014 77.

35. Seybold SD (2015) Somebody’s Watching Me: Civilian Oversight of Data-Collection Technologies. Texas Law Rev 93: 1029-60.

36. Lewis C (2000) Police complaints in metropolitan Toronto: Perspectives of the public complaints commissioner. In A. Goldsmith, ed. Complaints against the police: The trend to external Oxford: Clarendon Press review 153-77.

37. Calderon EL, Hernandez-Figueroa M (2013) Citizen oversight committees in law enforcement. California State University Fullerton 1-16.

38. De Angelis J, Kupchik A (2007) Citizen oversight, procedural justice, and officer perceptions of the complaint investigation process. Policing: Int J Police Strategies Management 30: 651-71.

39. Brown B (2015) Cops and Chaos: A Historical Examination of the Police Role in Riot Control. J App Security Res 10: 427-65.

40. Gorringe H, Stott C, Rosie M (2012) Dialogue Police, Decision Making, and the Management of Public Order During Protest Crowd Events. J Investigat Psychol Offender Profil 9: 111-25.

41. Morrell K, Currie G (2015) Impossible Jobs or Impossible Tasks? Client Volatility and Frontline Policing Practice in Urban Riots. Public Admin Rev 75: 264-75. 42. Lord VB, Friday PC (2003) Choosing a career in police work: A comparative study between applicants for employment with a large police department and public high school students. Police Practice Res 4: 63-78.

43. Johnson R (2012) A decision-making approach for offering risk assessment ratings in forensic psychological evaluations of police officers. Proceedings of the American Academy of Forensic Sciences 18: 437.

44. Johnson R (2011) The integration section of forensic psychological evaluation reports in law enforcement: Culturally responsive ending words. In Kitaeff J, ed, Handbook of police psychology. New York, NY: Routledge-Taylor.

45. Johnson R (2012) Use of police culture and ethics as a decision making resource in forensic pre-employment: Psychological evaluations of police officer applicants. Proceedings of the American Academy of Forensic Sciences 18: 436.

46. Clarke S (2009) Arrested oversight: A comparative analysis and case study of how civilian oversight of the police should function and how it fails. Columbia J Law and Social Problems 43: 31.

47. Sprott JB, Doob AN (2009) The effect of urban neighborhood disorder on evaluations of the police and courts. Crime Delinquency 55: 339-62.

48. Johnson R, Grieder, K, Descanio K (2012) Forensic role of clinical mental health professionals in on-scene risk assessment responses in collaboration with police. The Therapist 24: 61-3.

49. Huisman K, Martinez J, Wilson C (2005) Training police officers on domestic violence and racism: challenges and strategies. Violence Against Women 11: $792-821$.

50. Johnson R, Kim J, Touckly C, Lara, Young, Derrick (2016) Internal Police Officer Psychocultural Conflict over Race and Racism: An Officer Safety Paradigm. Paper presented at the 53rd Academy of Criminal Justice Sciences Conference, Denver, CO.

51. Johnson R, Jones P, Matteson R, Young Derrick (2016b) Role of Citizen Review Boards as Police Accountability and Ethnoracial Trust Resources in Diverse Communities. Paper presented at the 53rd Academy of Criminal Justice Sciences Conference, Denver, CO.

52. Nelson T, Sanbonmatsu K, McClerking H (2003) Perceiving racism in a police encounter. Australian J Psychol Supplement 55: 55.

53. Walker S (2002) Police accountability: Current issues and research needs. Paper presented at NIJ Police Planning Research Workshop, Nov 28-9, 2006, Washington, DC.

54. Perez DW (1994) Common sense about police review. Philadelphia, PA: Temple University Press. PO Darren Wilson.

55. Manning PK (2009) Bad cops. Criminol Public Policy 8: 787-94.

56. Johnson R (2013) Biopsychosociocultural perspective on 'Operation Enduring Freedom/Operation Iraqi Freedom’ women veterans as civilian police officers: mild traumatic brain injury and post-traumatic stress disorder challenges. Int J Police Strategies Management 15: 45-50.

57. Frühling H (2007) The impact of international models of policing in Latin America: The case of community policing. Police Practice Res 8: 125-44.

58. Schaible LM, De Angelis J, Wolf B, Rosenthal R (2012) Denver's citizen/police complaint mediation program: Officer and complainant satisfaction. Criminal Justice Policy Rev 24: 626-50.

59. Walker S (2005) The new world of police accountability. Thousand Oaks, CA: SAGE.

60. Johnson R, Greider K (2012) Use of law enforcement oath of honor in forensic psychological evaluations of police officers. Proceedings of the American Academy of Forensic Sciences 18: 436.

61. Christopher Commission. Independent Commission on the Los Angeles Police Department (1991). Report of the independent commission on the Los Angeles police department. Lost Angeles, CA: Author.

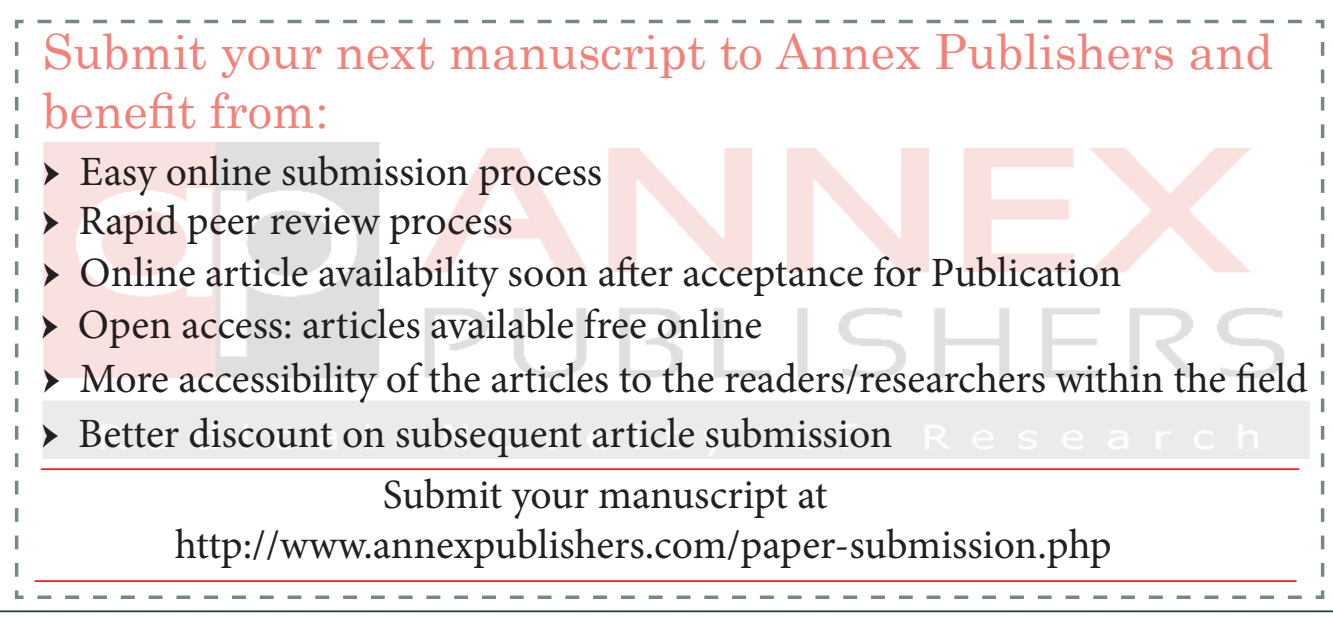

